Proc. NIPR Symp. Polar Meteorol. Glaciol., 10, 161, 1996

\title{
ANNUAL VARIATION OF TOTAL OZONE AT SYOWA STATION, ANTARCTICA (ABSTRACT)
}

\author{
Shigeru ChuBachI
}

Meteorological Research Institute, 1-1, Nagamine, Tsukuba 305

This paper discusses annual changes in total ozone during the polar night at Syowa Station $\left(69^{\circ} \mathrm{S}\right.$, $40^{\circ} \mathrm{E}$ ), Antarctica. The total ozone is almost constant from early June to early August each year. The springtime decrease in total ozone started in early September in 1982-1990 and in middle August in 1991-1992. The rate of total ozone decrease in August is less than 1.0 DU (Dobson Units) per day in 1982-1987 and increased to around 4.0 DU per day in the 1990s. The rate in September was around 1.0 DU per day in the $1980 \mathrm{~s}$ and was around $2.0 \mathrm{DU}$ in the $1990 \mathrm{~s}$.

The very low total ozone in September and October in the early 1990s is due to the rapid decrease of total ozone in August and the early start of decrease of total ozone in the Antarctic stratosphere.

Final warming at Syowa Station has been delayed 1.2 days per year annually. This fact suggests that the large ozone decrease over Antarctica affects the meteorology in the stratosphere over Antarctica.

(Received January 8, 1996; Revised manuscript accepted May 27, 1996) 